\title{
A Revolução dos Cravos e a Literatura para a Infância e a Juventude
}

\author{
José António Gomes \\ Escola Superior de Educação \\ Politécnico do Porto \\ https://orcid.org/0000-0001-9593-302X \\ [Recibido, 12 setembro 2019; aceptado, 23 xuño 2020]
}

[Gomes, J. A. (2020). A Revolução dos Cravos e a Literatura para a Infância e a Juventude. Boletín Galego de Literatura, 56, "Estudos", 41-63]

DOI http://dx.doi.org/10.15304/bgl.56.6266

RESUMO O 25 de Abril de 1974 é uma data marcante da história do Portugal do século XX, tendo constituído ponto de partida para numerosas obras musicais, literárias, teatrais, plásticas, cinematográficas e televisivas. A resistência contra a ditadura de quarenta e oito anos de Salazar e Marcello Caetano, a par do início da construção do Portugal democrático têm sido também tematizados em diversos livros para a infância e a juventude, com destaque para os textos narrativos, ainda que a lírica e o drama abordem igualmente o tema. Escritores de referência como Manuel António Pina, António Torrado, Luísa Ducla Soares ou Álvaro Magalhães, e ilustradores como João Abel Manta, Manuela Bacelar, António Modesto, Alex Gozblau, Evelina Oliveira e outros, não ficaram indiferentes a este marco histórico, e têm assim concorrido, através das suas obras, para a construção de uma memória, muito necessária às novas gerações, educadas já em democracia. É uma panorâmica crítica atualizada dessa produção-que se intensificou a partir da década de noventa do século XX- o que neste artigo é proposto. PalaVRAS ChaVE Literatura para infância e a juventude; Portugal; ditadura; 25 de Abril de 1974.

ABSTRACT April 25, 1974 is a remarkable date in the history of Portugal in the 20th century, having been the starting point for numerous musical, literary, theatrical, plastic, cinematographic and television works. Resistance against Salazar and Marcello Caetano's forty-eight-year dictatorship, along with the beginning of the construction of democratic Portugal, has also been addressed in several books for children and youth, with emphasis on narrative texts, albeit lyrical and drama also address the topic. Reference writers like Manuel António Pina, António Torrado, Luísa Ducla Soares or Álvaro Magalhães, and illustrators like João Abel Manta, Manuela Bacelar, António Modesto, Alex Gozblau, Evelina Oliveira and others, were not indifferent to this historical landmark, and have thus contributed, through his works, to the construction of a memory, very necessary for the new generations, already educated in democracy. This article proposes an updated critical overview of this production, which has increased since the nineties of the twentieth century.

KEYWORDS Literature for children and youth; Portugal; dictatorship; April 25, 1974. 


\section{Algumas considerações preliminares}

Numa entrevista de 22 de Março de 2019, o escritor angolano José Eduardo Agualusa (Lucas, 2019) afirma: "A política é tudo. E o que é a literatura? Os livros são territórios de debate. Se um livro não servir para fazer pensar na sociedade em que se vive, serve para quê? [...] Em contextos [...] [em que a maioria das pessoas não consegue fazer ouvir a sua voz] ainda é mais necessário que a literatura cumpra esse papel. Mas acho que toda a literatura o faz. Ou é literatura ou é entretenimento".

Liguemos estas palavras ao reconhecimento de que não existe literatura, nomeadamente literatura para a infância e a juventude, sem ideologia. Por muito que o autor o não deseje, ou mesmo quando disso não tem consciência. São frequentes, aliás, os estudos sobre a questão da ideologia nos livros infanto-juvenis (leia-se Khéde, 1980; Rosemberg, 1984; Stephens, 1992; Keyes \& McGillicuddy, 2014, e muitos outros) e a ideologia, como se sabe, é conceito especialmente relevante na teoria e na análise literárias, como evidenciam o Glossário da Crítica Contemporânea, de Marc Angenot (1984) ou o E-dicionário de termos literários dirigido por Carlos Ceia (leia-se o artigo "Ideologia" de António Lopes (2009)). Angenot começa por mencionar o conhecido conceito althusseriano na sua entrada sobre "Ideologia", conceito que neste artigo reassumimos: "Uma ideologia é um sistema (possuindo a sua lógica e o seu rigor próprios) de representações (imagens, mitos, ideias ou conceitos segundo os casos) dotados de uma existência e de uma função histórica no seio de uma sociedade dada" (Althusser citado por Angenot, 1984, pp. 120-121). Fazemos nossas ainda as palavras de Gemma Lluch, quando refere que "en el caso de la ideología y la literatura infantil y juvenil, hablaríamos de ideas, normas, valores, creencias, opiniones, prejuicios o actitudes próximas a la emotividad y creada a partir de los múltiples mecanismos que permite una narración. A partir de esta definición, afirmamos que todo relato transmite una determinada visión ideológica" (Lluch, 2003, p. 33). Quanto aos recursos a que o discurso literário deita mão e que, em relação estrutural de cada um deles com todos os outros, ativam a leitura da dimensão ideológica da obra, é de sublinhar que tais recursos são múltiplos, começando pelas opções ideotemáticas, genológicas, retóricas e estilísticas, mas englobando também aspetos como "la parodia de determinadas actitudes, la perspectiva que adopta el narrador, el personaje al que se le da protagonismo, la valoración de determinadas conductas o opiniones dentro del relato, las partes del mundo que se 
muestran y que se esconden, el tipo de lectura que se propone, las relaciones intertextuales que se valoran, etc" (Lluch, 2003, p. 35).

Por outro lado, quer o termo quer o conceito de revolução são ideologicamente conotados como nenhuns outros. E muitos são os contextos possíveis de aplicação de uma palavra como esta, sendo comum falar-se em revolução industrial, revolução tecnológica, revolução no pensamento, revolução nos costumes, revolução sexual, revolução dos corpos celestes...

Neste artigo, porém, adotaremos o conceito de revolução enquanto "mudança brusca e violenta na estrutura económica, social ou política de um Estado", como a define o Dicionário Priberam da Língua Portuguesa (2019), que exemplifica com a Revolução Francesa; mas muitas outras poderiam ser referidas: a Revolução Socialista de Outubro na Rússia, por exemplo -que aliás inspira o prolífico escritor britânico de literatura para crianças e jovens, Geoffrey Trease (1909-1998), em The White Nights of St Petersburg (1967), publicado, em Portugal em 1978, sob o título As Noites Brancas de São Petersburgo, pela Plátano Editora, na colecção Plátano de Maio, então sob a orientação de António Torrado. Sendo as revoluções sociais e políticas temática de tratamento frequente na literatura moderna e contemporânea, a escrita para a infância e a juventude não foge a esta regra, como veremos ${ }^{1}$.

Assumamos, pois, o risco ideológico de referir que momentos ou episódios como a chamada "Revolução ucraniana de 2014" -que preparou terreno para o ascenso do neo-nazismo na Ucrânia- ou as chamadas Primaveras árabes não constituem, a nosso ver, revoluções. Quando muito, estamos perante involuções sociopolíticas ou contra-revoluções de consequências em geral trágicas para os povos, e favoráveis não ao progresso e à justiça, mas antes às elites sócio-económicas que os dominam ou aos interesses geopolíticos e económicos de uma grande potência.

Por isso, quando o mediador propõe aos mais jovens a leitura de obras literárias que abordam conteúdos relacionados com revoluções políticas, julgamos que, enquanto intelectual e mediador, deve equacionar primeira-

\footnotetext{
Sobre a temática da Revolução dos Cravos na escrita para crianças e jovens, merecem leitura atenta o artigo, de Ana Margarida Ramos (2006), "Memórias da Revolução de Abril na Literatura para a Infância: diferentes formas de contar a mesma história", e ainda um segundo trabalho publicado pela mesma estudiosa oito anos depois (Ramos, 2014).
} 
mente a revolução de que está a falar, e refletir sobre a sua própria posição ideológica em relação a ela. Tudo isto, cremos, merece séria ponderação, porque neste campo a neutralidade é, a nosso ver, indesejável, muitas vezes praticamente impossível, e o conhecimento da História e a leitura crítica dos acontecimentos representados na obra constituem, portanto, requisitos de que o mediador não pode prescindir.

Pela nossa parte diremos: em Portugal, o 25 de Abril de 1974 e os tempos que se lhe seguiram, sensivelmente até 25 de Novembro de 75, ou seja, a chamada Revolução dos Cravos, não obstante o seu caráter essencialmente pacífico, foi efetivamente uma "mudança brusca e violenta na estrutura económica, social e política" do Estado Português. E teve implicações colossais, porque, desde logo, considerando os processos de descolonização que se seguiram, esteve na origem de seis outros estados soberanos -Angola, Moçambique, Guiné-Bissau, Cabo Verde, São Tomé e Príncipe e, mais tarde, Timor-Leste- tendo sido, do ponto de vista do autor deste artigo, um dos mais belos, generosos e progressivos acontecimentos sociais e políticos do século XX na Europa. Com muito de poético e artístico, acrescente-se, quer em virtude das canções e outras peças musicais que lhe estão associadas, e os poemas, os murais, os cartazes, as pinturas e esculturas a que deu origem, quer devido à presença dos cravos vermelhos nos canos de espingardas e nas mãos do povo, flores que viriam a converter-se em símbolo da própria Revolução portuguesa e a marcar toda uma iconicidade a ela associada, designadamente na linguagem artística, e, consequentemente, na ilustração dos livros infanto-juvenis. Será pois difícil encontrar um livro para crianças e jovens relacionado com Abril de 1974 que, na sua capa ou nas ilustrações, não contenha a representação de um cravo vermelho.

Com o 25 de Abril e o processo revolucionário que lhe sucedeu, ruiu um regime ditatorial de quarenta e oito anos e, durante algum tempo, chegaram a ser postos em xeque, numa perspetiva popular e anticapitalista, os pilares de um sistema socioeconómico profundamente injusto, em que as desigualdades eram gritantes. Na realidade, alguns grupos económicos monopolistas, um núcleo reduzido de famílias e os grandes latifundiários do Ribatejo e do Alentejo dominavam até 1974 a economia, mantendo na penúria e na pobreza boa parte da população portuguesa, sujeita à exploração e ao obscurantismo. Duas dinâmicas revolucionárias cruciais, entre outras, contribuíram para a "mudança brusca e violenta" já referida: o processo de nacionalização 
de bancos, companhias seguradoras e outras grandes empresas, e a Reforma Agrária, com ocupação de terras, nos campos do sul. Noutro plano, teremos de falar do fim da Guerra Colonial e da descolonização. E, finalmente, será necessário lembrar a extinção da PIDE, uma polícia política repressiva e que recorreu durante décadas e décadas à tortura e ao assassínio de opositores; a libertação dos presos políticos; o fim da Censura aos media e às artes; a par de todo o processo de democratização da sociedade e da própria liberalização dos costumes que a Revolução dos Cravos desencadeou, no quadro de uma ampla participação popular cuja dinâmica excedeu os propósitos iniciais do MFA (Movimento das Forças Armadas).

Tivemos ocasião de participar ativamente no processo revolucionário (em Portugal conhecido por PREC), na sequência de uma breve militância antifascista, anterior a Abril de 1974, ainda nos primórdios da nossa vida estudantil universitária -situação a que aludimos en passant no livro Lembro-me, graficamente concebido por Ana Biscaia, e assinado com o pen name, João Pedro Mésseder (2013).

\section{Os diferentes tipos de obras relacionadas com a Revolução}

Nos primeiros anos após Abril de 1974, os livros em torno da Revolução eram compreensivelmente escassos -os ecos e a memória dos acontecimentos estavam ainda vivos. A partir sobretudo do vigésimo aniversário do 25 de Abril (1994), assistiu-se a um crescente interesse dos escritores de literatura para a infância e a juventude pela Revolução dos Cravos. As criações em causa ficam sobretudo a dever-se às gerações de autores que, em 1974, contavam entre dezoito e cinquenta a sessenta anos, como se, tantos anos decorridos sobre essa data fulcral da nossa História do século XX, e face ao acumular de desilusões políticas e retrocessos sociais, se sentisse a necessidade de avivar memórias, de lutar contra o crescente branqueamento de um passado iníquo e dos seus crimes, de sublinhar o significado da Revolução bem como a importância das suas conquistas: liberdade, democracia, direitos sociais, possibilidade de luta por uma sociedade mais justa. Começaram, além do mais, a sentir-se os efeitos da passagem do tempo: jovens e crianças nascidos já depois de 1974 iam perdendo as referências históricas, situação agravada por uma crise crescente no ensino e aprendizagem da História que hoje atinge 
um ponto alto. E este é, sem dúvida, um dos grandes problemas com que se confrontam os criadores interessados em abordar a temática.

Quando, em 2007, sob o nome literário de João Pedro Mésseder, publicámos Romance do 25 de Abril em Prosa Rimada e Versificada, com ilustrações de Alex Gozblau, as nossas preocupações não andavam longe das enunciadas. Para o inscrever numa tradição literária que possui também uma vertente oral popular, escrevemo-lo em forma de romance tradicional, em verso rimado e ritmado (mais facilmente memorizável, dizível e cantável), recorrendo a uma figura alegórica (o menino Portugal, em que muitos e muitos portugueses se poderiam reconhecer), dando a ver o contraste entre as trevas do antes e a luz da liberdade pós-25 de Abril e deixando, de passagem, ecoar na escrita, numa intencional assunção de diálogo intertextual, as vozes de alguns dos grandes cantores da liberdade: os poetas Jorge de Sena, Sophia de Mello Breyner Andresen, Ary dos Santos, Manuel Gusmão. Fizemos também questão, neste livro, de não deixar cair no esquecimento o papel desempenhado, no desgaste e derrube da ditadura, pela única força política que, durante 48 anos, na clandestinidade, teve condições organizacionais para se opor ao salazarismo/marcelismo. Daí a personagem do "homem da bicicleta", imagem do antifascista clandestino.

Sidónio Muralha, com O Companheiro (1975), alguns contos de Sete Cavalos na Berlinda (1977), Catarina de Todos Nós (1979) e Terra e Mar, Vistos do Ar (1981), Manuel António Pina com “A revolução das letras" (incluído em $O$ Têpluquê, 1976), Matilde Rosa Araújo, com "História de uma Flor" (in A Velha do Bosque, 1983) ${ }^{2}$ foram dos primeiros escritores a remar contra o esquecimento quer da ditadura e dos seus crimes quer da importância da Revolução e da liberdade que ela refundou. Voltariam ao tema do antes e do pós-25 de Abril Manuel António Pina com o notável conto O Tesouro (1994) e Mário Castrim com a novela para jovens O Caso da Rua fau (1994). Deram conti-

2 Na sua Bibliografia Geral da Literatura Portuguesa para Crianças, Natércia Rocha (1987, p. 39) data de 1976 a primeira publicação deste conto, incluído em Vamos Contar... Três Histórias, de Matilde Rosa Araújo e Manuel Ferreira, com ilustrações de José Soares Rocha -um pequeno livro sem indicação de data editado pelo Ministério da Educação e Investigação Científica, pela Secretaria de Estado dos Desportos e Juventude e pelo Fundo de Apoio aos Organismos Juvenis, na coleção Cadernos Juventude e Cultura (n. $\left.{ }^{\circ} 12\right)$. Cremos, contudo, que se trata de um engano, já que este volumezinho de 24 páginas tem como data de Depósito-Legal o ano de 1986. Antes, nove anos depois da Revolução, como foi dito, havia sido incluído no livro de Matilde Rosa Araújo (1983), A Velha do Bosque. 
nuidade a este trabalho de construção da memória Isabel César Anjo, Maria Isabel Pereira e Alberto Pedroso (em 25 de Abril Sempre, 1994), José Jorge Letria, em O 25 de Abril Contado às Crianças e aos Outros (1999) e Capitães de Abril (1999); Alice Vieira, em Vinte e Cinco a Sete Vozes (1999); José Vaz, em A Fábula dos Feijões Cinzentos (2000); Maria Manuela Cruzeiro e Augusto José Monteiro em 25 de Abril: Outras maneiras de contar a mesma bistória (2000), António Torrado, na divertida narrativa em verso Vassourinha-entre Abril e Maio (2001); Álvaro Magalhães, em O Rapaz da Bicicleta Azul (2004); Vergílio Alberto Vieira, em A Revolução das Letras: o 25 de Abril explicado às crianças (2004); Álvaro Cunhal, em Os Barrigas e os Magriços (2005; ed. em livro, 2009 e 2018); e Margarida Fonseca Santos, em 7 x 25 Histórias da Liberdade (2010).

Sem o propósito de sermos exaustivos, registamos outros autores: Maria Mata -pseudónimo da premiada escritora Teresa Saavedra- (L. A. \& C. ${ }^{a}$ no Meio da Revolução, 1996, uma novela juvenil), Valdemar Cruz (O Soldado e o Capitão, os Cravos e o Povão, 1998), Paula Cardoso Almeida (Anos de Ditadura: Salazar, 2007, e 25 de Abril: Revolução dos Cravos, 2008), Luísa Ducla Soares ("Dia da Liberdade", em O Livro das Datas, 2009), Ana Oliveira (Do Cinzento ao Azul Celeste, 2009), João Manuel Ribeiro (O Rapaz sem Orelhas de Burro, 2011), Augusto José Monteiro (Em Abril, Histórias Mil..., 2012), José Fanha (Era Uma Vez o 25 de Abril, 2014) e Alexandre Honrado (25 de Abrir: O Abril que nos fez, 2014).

Em todos os casos, estamos a falar de textos narrativos, de extensões e características diferenciadas, nem sempre com os mesmos públicos-alvo: há obras mais simples para crianças, obras para adolescentes, e obras de receção transgeracional.

São de referir ainda narrativas para jovens (poucas) que, já muito depois de Abril de 1974, abordaram os modos de enfrentar e ludibriar a repressão policial no tempo do fascismo por parte de quem lutava pelos seus ideais ( $A$ Bandeira Escondida, 1998, de Arsénio Mota) ou a questão das famílias comunistas a viverem na clandestinidade (a novela juvenil Os Meus Misteriosos Pais, 2009, de José Viale Moutinho). De passagem mencionem-se também certas obras para jovens, de cunho biográfico (e sublinhe-se a relevância do género biográfico na formação cívica das gerações mais novas), prestando homenagem a artistas salientes que igualmente foram grandes lutadores pela liberdade e pela democracia, como Zeca Afonso e a Malta das Cantigas (2002), O 
Menino que se Apaixonou por Uma Guitarra: Carlos Paredes (2004), Zeca Afonso: o andarilho da voz de ouro (2007), ou que se destacaram pela sua atitude ética e pelo seu humanismo e heroísmo, quer no tempo do fascismo -Aristides de Sousa Mendes: um homem de coragem (2004)- quer durante o processo revolucionário: Salgueiro Maia - O Homem do Tanque da Liberdade (2004). Todos estes cinco livros são assinados pelo mesmo escritor, José Jorge Letria, ele próprio cantautor de intervenção, tal como José Afonso, antes e depois do 25 de Abril. Letria que, acrescente-se, dedicará ainda um relato infanto-juvenil ao longo, conflituoso e trágico processo de libertação da antiga colónia portuguesa de Timor: Timor Contado às Crianças... e aos Outros (1999).

Também na poesia encontraremos diversos exemplos de tratamento de tópicos relacionados com a Revolução dos Cravos. Já em 1977, Carlos Pinhão publicava um curioso bestiário intitulado Bichos de Abril, com vários poemas referindo direta ou indiretamente, a Revolução; a qual era aludida também numa ou noutra composição de Voa Pássaro Voa (1978), de Sidónio Muralha, e no belo Nome de Flor (1979), de Mário Castrim. Luísa Ducla Soares dedica um poema ao "25 de Abril" no seu excelente livro A Cavalo no Tempo (2003) e, uma década depois, João Manuel Ribeiro, José António Franco e Maria da Conceição Vicente publicam, a três, a colectânea de poemas para jovens, 25 de Abril: 40 anos de Liberdade (2013). O poemário Amigos em Todo o Mundo (1979), de Leonel Neves, é, por seu lado, devedor de certo espírito internacionalista, solidário e defensor da convivência pacífica entre os povos que marcou os anos de 1974, 75 e seguintes. Já Viagem à Flor de um Més (2002), de José Jorge Letria, com belas ilustrações do seu filho André Letria, é um tocante poema em forma de diálogo entre um pai e um filho (nascido no ano da Revolução) que, evocando a magia e significado do dia 25 de Abril de 1974, não deixa de ser revelador de alguma melancolia relativamente à distância a que "a festa” já se encontra. Certa tristeza, cansaço desprendem-se pois das palavras do pai, garantindo-lhe no entanto o filho que manterá viva "a corola desse mês / chamado Abril” (Letria, 2002, p. 43).

Fazemos pois referência a perto de cinco dezenas de títulos, o que, no contexto português, representa um considerável volume de obras, ao longo de quarenta e seis anos. Pode-se, pois, dizer que o antes, o durante e o pós-Revolução foram sendo recriados em várias e diferentes escritas. Não se pode é afirmar que todas estas obras sejam literárias, mesmo quando são produzidas por escritores, porquanto contamos com: 
1. Relatos de tipo mais informativo e historiográfico, de qualidade muito desigual nos planos da estrutura e da escrita (os textos de Isabel César Anjo, Maria Isabel Pereira e Alberto Pedroso; de Maria Manuela Cruzeiro e Augusto José Monteiro; de Paula Cardoso Almeida; de José Fanha; e mesmo alguns dos livros de Letria) -relatos onde, aliás, são detetáveis visões diferenciadas, e ideologicamente marcadas (algumas discutíveis até) sobre os acontecimentos históricos ${ }^{3}$;

2. Textos biográficos sobre destacados cidadãos e artistas que pugnaram pela liberdade (vejam-se os de José Jorge Letria sobre Salgueiro Maia, Carlos Paredes, José Afonso);

3. Textos narrativos breves, para leitores iniciais (como os já mencionados de Álvaro Cunhal, Vergílio Alberto Vieira, José Vaz, Torrado, Pina...), do tipo conto ilustrado ou com formato álbum, em registo fabular ou alegórico, ou seguindo uma linha mais ou menos realista;

4. Textos narrativos para leitores medianos, do tipo conto ou novela ilustrados (Arsénio Mota, Álvaro Magalhães, Valdemar Cruz...) ou adoptando a forma de narrativa em verso, na esteira do romance tradicional (Mésseder);

5. Novelas para pré-adolescentes e adolescentes, de diferentes tipos, mas de registo tendencialmente realista (Mário Castrim, Maria Mata, Viale Moutinho, Alice Vieira...);

6. Poemas soltos e poemários (Carlos Pinhão, Muralha, Castrim, Luísa Ducla Soares, Letria... $)^{4}$.

3 Vejamos um dos casos em que a questão ideológica ganha relevo particular no tratamento da História contemporânea pela escrita para crianças e jovens. José Fanha, por exemplo, em Era Uma Vez o 25 de Abril, e ao longo deste longo e interessante livro de oitenta e seis páginas, que chega a esboçar um percurso pela História do século XX, obra graficamente muito rica (com tratamento visual de colantes, cartazes, fotos, documentos...), Fanha, dizíamos, comete a proeza de não fazer uma só referência à única força política organizada, como é reconhecido pela generalidade dos historiadores, o Partido Comunista Português (PCP), que, ao longo de quarenta e oito anos, lutou contra o fascismo e pela liberdade, com dezenas e dezenas de militantes presos e assassinados - ainda que não deixe de mencionar a fundação do Partido Socialista Português em... 19 de Abril de 1973. Mário Soares, histórico fundador e dirigente do Partido Socialista, mais tarde primeiro-ministro e presidente da república de Portugal, é referido algumas vezes, tal como Álvaro Cunhal (duas vezes), sem no entanto se indicar sequer a proveniência política deste que talvez tenha sido, enquanto dirigente e secretário-geral do PCP, o mais famoso prisioneiro político do salazarismo, além de figura de dimensão internacional, como é reconhecido por historiadores de centro-direita, insuspeitos de simpatia política, como José Pacheco Pereira (1999, 2001, 2005 e 2016).

4 Merecem referência ainda outras obras relacionadas com a Revolução dos Cravos, tais como, de José Jorge Letria (1999), Era Uma Vez um Cravo, e, de Conceição Lopes (1999), Vinte e Cinco de Abril quase como Um Conto de Fadas. Também em relação à poesia para crianças e jovens, a lista de exemplos proposta não se quer exaustiva; outros poderão ser apontados. 
Além de se notar uma ausência total do texto dramático -tanto quanto nos é dado conhecer, embora existam frequentes adaptações teatrais e leituras encenadas de algumas das narrativas mencionadas-, diga-se que é sobretudo nos conjuntos 3 a 6 que descobrimos o investimento na literatura: a ficcionalização a partir da base histórica, o conflito próprio da narrativa, o desenvolvimento maior da categoria personagem, o jogo de diferentes vozes narrativas nas obras para jovens, o cunho fabular ou alegórico de alguns textos para os mais novos, a maior ou menor poeticidade da linguagem...

Com algumas excepções (Os Barrigas e os Magriços, de Álvaro Cunhal, $L$. A. \& C. ${ }^{a}$ no Meio da Revolução, de Maria Mata, O Soldado e o Capitão, os Cravos e o Povão, de Valdemar Cruz, O Rapaz da Bicicleta Azul, de Álvaro Magalhães, Romance do 25 de Abril, de João Pedro Mésseder e alguns mais) a recriação literária das agitadas cenas de multidão nas ruas ou em ocupações de terra não é tão frequente assim. Dificuldades diversas? Complexidade a mais? Receio de ferir suscetibilidades políticas e ideológicas? Talvez. Em alguns livros opta-se por isso pela exploração de aspectos nos quais o leitor jovem, que não viveu a Revolução, se pode rever, com vista a uma melhor compreensão das alterações provocadas pelo 25 de Abril: por exemplo, a escola da ditadura e a escola da democracia, ou as relações de namoro entre adolescentes, antes de Abril de 74 e depois, como se observa na novela O Caso da Rua Fau, de Castrim. Recorre-se ainda (por exemplo em Vinte e Cinco a Sete Vozes) à sucessão/ cruzamento de testemunhos, em diferentes registos de língua, correspondentes a estratos socioculturais distintos, sobre o significado do acontecimento histórico, seja na perspectiva de jovens adultos e adolescentes do final de década de noventa do século passado, seja na perspectiva de idosos e outras personagens que viveram intensamente a luta contra o fascismo e os dias da Revolução.

Em outros casos, e pensando sobretudo nos mais novos, ou seja, em leitores iniciais, o escritor opta, como já se disse, por uma construção fabular ou alegórica para figurar a Revolução, seus antecedentes e suas consequências, já que não pode contar com um conhecimento prévio de referentes históricos suficientes por parte da criança. E, em contextos deste tipo, realça sobretudo a oposição entre opressores e oprimidos, entre poderosos e espoliados, como forma de salientar mais valores e atitudes em confronto, e menos a realidade histórica propriamente dita. 


\section{Alguns títulos a destacar}

Tomemos alguns exemplos mais conseguidos da representação da Revolução em livros de recorte efetivamente literário.

Concentremo-nos num dos casos de maior criatividade: a breve narrativa "Romance da revolução das letras", do livro O Têpluquê, de Manuel António Pina (1976), pomposa e ironicamente dividida em quatro capítulos... brevíssimos. Com a linguagem escrita colocada no cerne do texto, visto as personagens principais serem as letras, o primeiro capítulo revela como, desde pequenas, as letras perguntavam às maiúsculas a razão da Ordem Alfabética. Respondiam-lhes "que tanto fazia" (Pina, 1976, p. 8) uma ordem como outra, mas o certo é que a Ordem Alfabética convencionada, dando o primeiro lugar a uma vogal e o último a uma consoante, lhes era ensinada/inculcada desde a infância, como algo de indiscutível -primeiro motivo de descontentamento.

O segundo capítulo, "As contas das letras", mostra um agravamento da situação, sublinhando a diferença entre uma minoria de privilegiadas, as vogais, e uma "esmagadora maioria" composta pelas consoantes. Consequência: não só em certas palavras, por exemplo "privilegiado", "só os is apareciam três vezes e o a uma e o e e o também uma cada um", como "embora a palavra privilegiado tivesse na sua Constituição seis vogais e outras seis consoantes, das vogais só ficava de fora o u (uma semivogal!), ao passo que das consoantes ficavam de fora ao todo 13!" (Pina, 1976, p. 10). Segundo o narrador, que vai dando voz ao descontentamento, já na palavra trabalhar "era o contrário; havia seis consoantes e só uma vogal, o a, que andava de uma sílaba para a outra para parecer que havia lá muitas vogais a trabalhar..." (Pina, 1976, p. 10). São de notar, em primeiro lugar, as conotações sociopolíticas dos termos escolhidos para expor a questão (privilegiado, trabalhar), bem como a referência à Constituição (usada em duplo sentido e grafada com maiúscula) da própria palavra privilegiado. O segundo motivo de descontentamento prende-se, em suma, com a diferença de direitos entre vogais e consoantes e com a ubiquidade de certas vogais que, assim, transmitem a falsa imagem de trabalhadoras.

O terceiro capítulo, intitulado "O scrtd", revela as contas que as letras principiaram a fazer à vida delas e como a televisão e os jornais "começaram a fazer reportagens e a ouvir as queixas das letras" (Pina, 1976, p. 12), em especial das consoantes que se organizaram e se constituíram em scrtd: "um 
secretariado só constituído por consoantes” (Pina, 1976, p. 12). Com notável sentido de humor, são expostos os "dramas terríveis" de certas consoantes em algumas frases e uma ameaça fica a pairar no ar: "as vogais tinham tanto medo das consoantes -que eram muitas mais- que só muito raramente as deixavam andar juntas e só às de mais confiança como o agá, que era meio vogal...” (Pina, 1976, p. 13). Este capítulo expõe, assim, o crescendo de descontentamento das vogais e o avanço para um patamar de afrontamento mais elevado, ou seja, o da informação, da propaganda e da luta organizada. Conota, por outro lado, a atitude repressiva das vogais com a ação de uma polícia política.

O quarto capítulo, intitulado "A revolução das letras", relata a insurreição:

Até que um dia, o dono do alfabeto, que era quem escrevia com ele, reuniu os seus gramáticos e disse:

- Façam qualquer coisa senão as letras revoltam-se. Ainda fazem alguma cooperativa e começam a escrever sozinhas!

Mas por mais leis que os gramáticos fizessem nunca mais conseguiram meter as letras na ordem alfabética. E depois das letras revoltaram-se as palavras, e depois os livros, e depois as bibliotecas, e depois tudo" (Pina, 1976, p. 14).

Atente-se nos receios da autogestão das letras e da perigosa constituição de uma cooperativa expressos pelo "dono" do alfabeto, bem como nas ondas de choque originadas pela insurreição das letras (qual vanguarda revolucionária) que acabam por provocar uma revolução total. Uma revolução que extravasa as letras e envolve livros, bibliotecas e "depois tudo". Ao leitor cabe adivinhar os possíveis sentidos deste "tudo", bem como a sequência que não é contada: rejeição de tutelas e de desigualdades?, imposição violenta de uma completa mudança social?, instauração de um novo regime, socialmente mais justo?

Lembraremos apenas que O Têpluquê é inicialmente editado em 1976, cerca de dois anos depois da Revolução dos Cravos e no mesmo ano em que era aprovada a Constituição que ainda hoje vigora, não obstante as várias revisões e desfigurações que foi sofrendo.

Não será esta a única vez que a escrita de Manuel António Pina (19432012) para crianças tematizará a revolução como coisa necessária, embora não sob a forma de uma espécie de parábola de cunho alegórico, como ocorre em $O$ Têpluquê. Além de alusões menos diretas descortináveis noutros livros, 
como em certas falas do Bobo, na peça de teatro História com Reis, Rainhas, Bobos, Bombeiros e Galinhas, que glosam o topos do mundo às avessas, é sobretudo em O Tesouro, editado em 1994, com ilustrações de Manuela Bacelar, que o tema é retomado.

Num primeiro momento, o conto estrutura-se a partir de um contraste entre duas linhas isotópicas, a da positividade e a da negatividade, em correspondência às duas realidades descritas: um país quase paradisíaco em termos de paisagem natural, de recursos, de afabilidade da população, mas habitado por pessoas tristes e espoliadas de um "tesouro": a liberdade. O retrato que se seguirá, numa prosa intencionalmente simples mas imbuída de poeticidade e lirismo, dá conta das provações do País das Pessoas Tristes, recorrendose ao que era ouvido pelos estrangeiros de visita ao país. O narrador refere então o medo, a falta de liberdade de expressão, os condicionamentos da vontade individual e também do desejo de conhecer a vida de outros povos, a omnipresença de uma polícia de vigilância e repressão, as incompreensíveis proibições ao nível dos costumes, a obrigatoriedade, para os rapazes, de participação numa guerra em países longínquos e desconhecidos onde muitos morriam ou ficavam "loucos ou estropiados" (Pina, 1994, p. 9) e, finalmente, a impossibilidade de escolher os governantes através de eleições livres.

A esta sombria primeira parte, segue-se o emotivo relato da revolução, espécie de luminoso momento fundador. É um quase poema em prosa, em que o tom lírico se acentua, convertendo os acontecimentos narrados num emocionante e emocionado momento genesíaco de conquista e expressão da liberdade de um povo (ver Pina, 1994, pp. 11-14).

Um registo coloquial instituíra, logo no incipit, um diálogo implícito entre narrador e narratário infantil ("Há muitos anos, no tempo em que o teu pai andava na escola, num país muito distante vivia um povo infeliz e solitário, vergado sob o peso de uma misteriosa tristeza" (Pina, 1994, p. 2), enraizando deste modo a matéria a contar num real que se quer marcado pela historicidade e por certo vínculo com o vivido (neste caso, pelo "pai" do narratário). O explicit irá confirmar a "verdade" do narrado e sublinhar esse enraizamento:

Tudo isto aconteceu há muito tempo (ainda tu não tinhas nascido), num país muito distante.

Esse país agora já não se chama País das Pessoas Tristes, chama-se Portugal e é o teu país. E o tesouro pertence-te a ti, és tu que agora tens que cuidar dele. [...] 
Porque esta história não é uma história inventada. É uma história verdadeira, aconteceu mesmo. Pergunta aos teus pais ou aos teus professores e eles contarte-ão mais coisas sobre o País das Pessoas Tristes e sobre o Dia da Liberdade (Pina, 1994, p. 14-15).

A revolução configura, em suma, um tópico relevante na escrita de $\mathrm{Ma}$ nuel António Pina, com óbvias implicações ao nível semântico-pragmático. Estamos perante obras que fizeram de certos valores (tais como a democracia, a liberdade, a justiça social, o direito inalienável de questionar a ordem estabelecida, o direito à revolta...), aspetos indissociáveis de outras dimensões do policódigo literário e pilares fundamentais do seu construto estético.

Outra obra merecedora de especial atenção é a de Álvaro Cunhal (19132005), histórico secretário-geral do PCP, entre 1961 e 1992, e talvez o mais famoso dos presos políticos e dos exilados pelo regime fascista de Salazar e de Caetano -além de ter sido apreciado desenhador, pintor, e ensaísta e novelista de mérito (neste caso com o pseudónimo Manuel Tiago), que viu diversas ficções suas publicadas, incluindo contos infantis.

Em Os Barrigas e os Magriços, o termo Barrigas surge conotado com boa vida, do ponto de vista socioeconómico, e com arrogância -corresponde ao nome, maiusculado, porque são conhecidos os habitantes de um país, minoritários, comilões e possuidores de quase tudo, por contraste com outros, os Magriços, habitantes maioritários do mesmo país, e trabalhando para os primeiros. Cito: "Nesses campos, nesses moinhos, nesses lagares [os pertencentes aos Barrigas], trabalhavam os Magriços. Mas recebiam tão pouco, tão pouco que não lhes dava para comerem eles, suas mulheres e seus filhos. E, ainda por cima, eram mesmo maltratados, como se fossem bichos" (Cunhal, 2018, p. 10).

No conto de Cunhal, o exemplo a não seguir, aquele cujo modo de estar na vida (à custa do trabalho de outros, esses sim os verdadeiros produtores de riqueza) é condenado, é naturalmente o dos Barrigas, claros representantes da classe dominante e exploradora. E pode-se afirmar que os que exibem traços de positividade são a classe dos Magriços. Pela consciência de classe que adquirem, pela união que põem em marcha, quer entre eles quer com os soldados, pela capacidade de resistência e de reivindicação de direitos e pela coragem. Finalmente, pelo sentido de organização que os leva a apropria- 
rem-se dos meios de produção e a laborar cooperativamente para o interesse comum, ou, se se preferir, a construir uma sociedade regida pelos valores do direito ao trabalho, da cooperação e da partilha, da igualdade e da justiça social. A história dos Magriços -valorizando aliás a força do colectivo, como noutras ficções de Manuel Tiago / Álvaro Cunhal (Até Amanhã, Camaradas, por exemplo)- é como que a prefiguração de uma sociedade socialista.

É avançada, chamemos-lhe assim, e obviamente marcada pelo marxismo do autor, a mensagem de Os Barrigas e os Magriços, cuja história incorpora a ideia da transformação revolucionária -ou não se estivesse a aludir à Revolução de Abril e, de algum modo, à coletivização da terra na Reforma Agrária de 1975, em Portugal.

O conto composto por Cunhal em 2000 e mais tarde reeditado, até sair em 2018 numa digna edição das Edições Avante!, com admiráveis ilustrações de Susana Matos, está escrito num registo buscadamente simples mas vivo e oralizante, com marcas de conversação e de interpelação ao destinatário "infantil" intratextual, como se pode ler no final (Cunhal, 2018, p. 34). Estrutura-se a partir de uma constante oposição, que também é visual, como assinala Ana Margarida Ramos (2014, p. 268), construída entre os Barrigas -e o que social e politicamente estes figuram, ou seja, a classe dominante respaldada pela ditadura fascista- e os Magriços, resistentes à força bruta e ao medo, representando o operariado agrícola, os trabalhadores e os descamisados em geral, apoiados a determinada altura pelos soldados, seus aliados na mudança e na defesa contra os coléricos Barrigas, sempre prontos a convocar as forças da repressão.

Já Mário Castrim (1920-2002), em O Caso da Rua fau (1994), oferecenos uma narrativa juvenil em que se aborda o significado do 25 de Abril, na perspetiva das alterações verificadas quer no relacionamento amoroso entre adolescentes quer no ambiente escolar. Marcado pelo humor e pelo sentido crítico, muito conseguido do ponto de vista técnico-narrativo e da escrita, e apostando numa alternância de vozes narrativas diferenciadas, de distintas faixas etárias, apresenta até recriações ficcionais de personagens reais -como a do próprio professor Fonseca (Mário Castrim era o pseudónimo de Manuel Nunes da Fonseca) e a de Matilde (que corresponde à sua amiga, a escritora e professora Matilde Rosa Araújo). Além de dar a ver as grandes diferenças sociais antes da Revolução, O Caso da Rua fau traça um contraste entre o 
ambiente repressivo e socialmente preconceituoso, em matéria de costumes e não só, nas escolas portuguesas antes de Abril de 1974, e a liberalização natural a que se assistiu nas décadas posteriores.

José Jorge Letria (n. 1951), por seu turno, propõe, em Capitães de Abril (1999), um relato vivo e lúcido da Revolução dos Cravos, tal como foi vivenciada por João e Teresa, um casal que em Abril de 1974 tinha cerca de vinte e cinco anos. A relação destas personagens com um filho entretanto chegado à idade adulta cria o quadro que permite ao narrador realçar a importância da memória e de transmitir às gerações mais novas o testemunho dos ideais de democracia e liberdade. Saliente-se o bom gosto do arranjo gráfico de José Pedro Costa -também autor das ilustrações- que, além de explorar o simbolismo da cor vermelha ao longo de todo o livro, reforça o enquadramento do texto no âmbito da crónica jornalístico-literária, através do tipo de fonte tipográfica seleccionada para o cabeçalho e para a numeração das páginas.

Outra aproximação consistente à história do 25 de Abril, enredada nos fios da ficção e da emoção, é Vinte e Cinco a Sete Vozes, saído por ocasião do vigésimo quinto aniversário da Revolução - texto de destinatário plural, isto é, não exclusivamente para jovens, embora algumas das suas personagens sejam adolescentes.

Constitui-se esta narrativa de Alice Vieira (n. 1943) a partir do cruzamento de sete perspetivas sobre o 25 de Abril, dadas por outras tantas vozes representativas de diferentes gerações, classes e modos de pensar -o que confere à obra uma dimensão poliédrica e problematizante, não manipuladora, mas que não escamoteia a referência aos aspetos mais negros da ditadura de Salazar e Caetano. Os testemunhos pertencem a jovens adultos e adolescentes do final de década de noventa do século passado, e ainda a idosos e a outras personagens que viveram de modo intenso a luta contra o fascismo e os dias da Revolução. Embora nunca escutemos a sua voz, uma jovem que prepara uma dissertação de mestrado sobre a memória dos acontecimentos (e que se constitui como "narrador silencioso", divulgador de depoimentos, e simultaneamente como narratário dos depoentes), essa jovem, dizíamos, grava os testemunhos mencionados, cujos autores se encontram ligados entre si por laços familiares ou de outro tipo. Estamos assim perante monólogos em diversos registos de língua que evocam ora o dramatismo do período anterior ao 25 de Abril, ora as alegrias da liberdade ou, no caso dos mais jovens, 
uma caricata falta de memória histórica, cuja responsabilidade é, em parte, assacada à Escola.

A par de outras, certamente, mereceriam ainda análise pormenorizada narrativas de qualidade como $O$ Rapaz da Bicicleta Azul, de Álvaro Magalhães (n. 1951), comovente recriação do dia 25 de Abril de 1974, na perspetiva de um rapaz, filho dum militante oposicionista perseguido pela polícia política do regime. Decidido a viver uma aventura num país pouco propício a ela, montado numa bicicleta nova e quase mágica que o transporta até Lisboa, a sua busca pela flor da liberdade leva-o a conhecer o capitão Salgueiro Maia (o mais mítico dos capitães de Abril), a descobrir a flor nos cravos vermelhos da Revolução e a reencontrar o pai.

Já a personagem principal de Beatriz e o Plátano (1976), de Ilse Losa (19132006), outro título ainda não mencionado neste trabalho, por não tematizar de forma direta a Revolução, apresenta a primeira protagonista infantil civicamente combativa da nossa literatura para a infância e a juventude, isto é, uma menina imbuída do espírito reivindicativo próprio da época, determinada na defesa de direitos para si própria e para os outros. Logrando animar e pôr em marcha um coletivo de moradores dum bairro, a fim de impedir o corte de um plátano, programado pelas autoridades, Beatriz é também uma das primeiras ambientalistas da nossa literatura para crianças. Uma heroína, ademais, feminista e produto de uma dinâmica revolucionária valorizadora da energia coletiva que, nesses anos exaltantes $(1974,75,76 \ldots)$, mudou a face do povo português e lhe devolveu brilho e dignidade.

\section{Considerações finais}

Com algumas exceções dignas de nota (Sidónio Muralha, Ilse Losa, Carlos Pinhão, Manuel António Pina...), a escrita para crianças e jovens do pós25 de Abril (1974 a 1977) não adotou como tema de eleição a realidade revolucionária e o seu significado histórico, político e cívico. No entanto, em especial a partir do início dos anos 90 do século XX, observa-se um interesse crescente pelo reavivar da memória do 25 de Abril, apresentando-se, muitas vezes, sobretudo na narrativa, um confronto entre os tempos opressivos e cinzentos do salazarismo e do marcelismo e os tempos da liberdade e da democracia reconquistadas em 1974 (exemplo paradigmático: O Tesouro, de 
Manuel António Pina). É como se as gerações nascidas após à Revolução, a chamada (por alguns) "normalização" democrática e o gradual apagamento da memória, sobretudo a partir dos anos 80, tivessem começado a motivar muitos criadores à recriação ficcional e poética dos aspetos mais negros da ditadura e da sua superação por um Movimento dos Capitães, cuja força se alimentou do próprio ímpeto progressista do movimento popular. Tal tendência ir-se-á acentuando, a ponto de hoje podermos dizer que é abundante o corpus merecedor de estudo: meia centena ou mais de obras publicadas, as quais de uma forma ou de outra abordam a temática, procedendo de modos diversos.

De referir que é mais profusa a produção literária para crianças do que a destinada a adolescentes, ambas contudo empenhadas em valorizar, invariavelmente, algumas das principais conquistas da Revolução, tais como a liberdade, a democracia política, o fim da repressão policial, o gosto pela intervenção cívica, a liberalização dos costumes, o fim da Guerra Colonial, a suspensão do fluxo migratório da população mais pobre, a possibilidade de construção de uma sociedade mais justa, etc.. $\mathrm{Na}$ escrita para os mais novos, a abordagem alegórica do tema e o confronto entre valores positivos e contravalores naturalmente negativos revestem-se de algum peso (como se verifica nas obras de Torrado, José Vaz, Vergílio Alberto Vieira ou mesmo Álvaro Cunhal), evidenciando as dificuldades em representar literariamente os episódios históricos recentes, nos seus contornos eventualmente controversos, perante um destinatário com capacidades de reflexão sobre a dinâmica histórica ainda muito limitadas, como é o público infantil. Quando se envereda por registos mais documentais (em obras situadas entre literatura e paraliteratura, como algumas de Letria e de Fanha) ou se propõe um relato ficcional de cariz realista é que as diferenças ideológicas entre autores/obras se tornam mais vincadas, designadamente nos modos de retratar personagens históricas e de equacionar os acontecimentos políticos, suas causas e consequências. A inquietação decorrente da eventual diluição da memória histórica surge também como um tópico não desprezível em algumas obras (como Vinte e Cinco a Sete Vozes, de Alice Vieira, ou Do Cinzento ao Azul Celeste, de Ana Oliveira).

Seja como for, o considerável número de títulos sobre o tema -contos ilustrados, novelas, poesia, mas ausência, ou quase, do texto dramático- não só confirma o 25 de Abril de 1974 como uma data charneira na História do Portugal contemporâneo, como sobretudo revela a preocupação generalizada 
de escritores e ilustradores em revalorizar a Revolução e o seu sentido democrático e progressista, fazendo dela matéria literária e objeto de recriação ficcional e poética. Parece procurar-se, assim, manter viva junto dos mais novos a chama de um momento efetivamente crucial no Portugal do século XX, contribuindo para a construção de uma consciência cívica e de uma memória histórica, bem necessárias na época em que vivemos. De facto, os inquietantes tempos de reascenso do fascismo que atravessamos, as manifestações de discriminação racial, de xenofobia, de violência de género, bem como o aumento das desigualdades sociais e os sinais de erosão dos regimes democráticos levam a que se encare a literatura em geral, e a escrita para a infância e a juventude em particular, não só como objeto de fruição estética mas também como mensagem interpeladora e suscetível de estimular a reflexão sobre as dinâmicas político-sociais.

\section{Referências}

Almeida, P. C. (2007). Anos de Ditadura - Salazar. Quidnovi [Ilustrações de Carla Nazareth com a colaboração de Patrícia Alves e Miguel Gabriel].

Almeida, P. C. (2008). 25 de Abril - Revolução dos Cravos. Quidnovi [Ilustrações de Carla Nazareth com a colaboração de Patrícia Alves e Miguel Gabriel].

Anjo, I. C., Pereira, M. I., Pedroso, A. (1994). 25 de Abril Sempre. Câmara Municipal de Coruche.

Araújo, M. R. (1983). História de uma flor. Em A Velha do Bosque (pp. 21-31). Livros Horizonte [llustrações de Ana Leão].

Castrim, M. (1979). Nome de Flor. Célula do PCP dos Trabalhadores da Renascença Gráfica / Diário de Lisboa [Ilustrações de Ermelinda de Sousa].

Castrim, M.(1994). O Caso da Rua Fau. Pelouro da Educação e Juventude da Câmara Municipal de Lisboa [llustrações de Jorge Barros].

Cruz, V. (1998). O Soldado e o Capitão os Cravos e o Povão. Campo das Letras [Ilustrações de João Caetano].

Cruzeiro, M. M., Monteiro, A. J. (2000). 25 de Abril - Outras Maneiras de Contar a Mesma História. Editorial Notícias - Casa das Letras [Ilustrações de Marta Rego]. 
Cunhal, Á. (2018). Os Barrigas e os Magriços. Página a Página [Ilustrações de Susana Matos $]^{5}$.

Fanha, J. (2014). Era Uma Vez o 25 de Abril. Alfaguara [Conceção gráfica de Jorge Silva / Silvadesigners].

Honrado, A. (2014). 25 de Abrir: O Abril que nos fez. Verbo [Ilustrações de Maria João Lopes].

Keyes, M. T., McGillicuddy, A. (Ed.) (2014). Politics and Ideology in Children's Literature. Four Courts Press.

Khéde, S. S. (1980). Literatura infanto-juvenil: ideologia e consciência. Tempo Brasileiro, 63 (Out/Dez), 34-35.

Letria, J. J. (1999a). Capitães de Abril. Ambar [Ilustrações de José Pedro Costa].

Letria, J. J. (1999b). Era Uma Vez um Cravo. Câmara Municipal de Lisboa [Ilustrações de André Letria].

Letria, J. J. (1999c). O 25 de Abril Contado às Crianças... e aos Outros. Terramar Editores [Ilustrações de João Abel Manta].

Letria, J. J. (1999d). Timor Contado às Crianças... e aos Outros. Lisboa: Terramar Editores [Ilustrações de João Mendonça].

Letria, J. J. (2002a). Zeca Afonso e a Malta das Cantigas. Terramar.

Letria, J. J. (2002b). Viagem à Flor de um Mês. Campo das Letras [Ilustrações de André Letria].

Letria, J. J. (2004). Aristides de Sousa Mendes: um homem de coragem. Terramar.

Letria, J. J. (2004). O Menino que Se Apaixonou por Uma Guitarra: Carlos Paredes. Campo das Letras [Ilustrações de José Emídio].

Letria, J. J. (2004). Salgueiro Maia - O Homem do Tanque da Liberdade. Terramar.

Letria, J. J. (2007). Zeca Afonso: o andarilho da voz de ouro. Campo das Letras [Ilustrações de Evelina Oliveira].

5 Inicialmente publicado em Visão, n. ${ }^{\circ}$ 662, 10 de Novembro de 2005, pp. 66-67; texto datado de 7 de Junho de 2000. 
Llhuch, G. (2003). Análisis de Narrativas Infantiles y fuveniles. Ediciones de la Universidad de Castilla-La Mancha.

Lopes, A. (2009). Ideologia. Em C. Ceia (Dir.), E-dicionário de termos literários https:// edtl.fcsh.unl.pt/encyclopedia/ideologia/ (consultado em 15-6-2020).

Lopes, C. (1999). Vinte e Cinco de Abril quase como Um Conto de Fadas. Livraria Civilização Editora [Ilustrações de Francisco Santarém].

Losa, I. (1976). Beatriz e o Plátano. ASA [Ilustrações de Lisa Couwenbergh].

Lucas, I. (22 de marzo de 2019). O que a comunidade internacional está a fazer em Moçambique "não é ajudar, é indemnizar por danos causados" (entrevista a José Eduardo Agualusa). Público. https://www.publico.pt/2019/03/22/mundo/ entrevista/eua-china-europa-indemnizar-mocambique-danos-aquecimentoglobal-1866492.

Magalhães, Á. (2004). O Rapaz da Bicicleta Azul. Campo das Letras [Ilustrações de António Modesto].

Mata, M. (1996). L. A. \& C. ${ }^{a}$ no Meio da Revolução. Civilização [Ilustrações de Susana Oliveira].

Mésseder, J. P. (2007). Romance do 25 de Abril. Caminho [Ilustrações de Alex Gozblau].

Mésseder, J. P. (2013). Lembro-me. Lápis de Memórias [Conceção gráfica de Ana Biscaia].

Monteiro, A. (2012). Em Abril, Histórias Mil... (as do 25 de Abril e outras). Lápis de Memórias [Ilustrações de Tiago Madeira].

Mota, A. (1998). A Bandeira Escondida. Campo das Letras [Ilustrações coligidas por Fernando Lanhas].

Moutinho, J. V. (2009). Os Meus Misteriosos Pais. Seara de Letras [Ilustrações de Acácio de Carvalho].

Muralha, S. (1975). O Companheiro. Futura, col. Nova Geração.

Muralha, S. (1977). Sete Cavalos na Berlinda. Plátano, col. Plátano de Abril [Ilustrações de Ana Machado].

Muralha, S. (1978). Voa Pássaro Voa. Horizonte [Ilustrações de Fernando Lemos]. 
Muralha, S. (1979). Catarina de Todos Nós. Caminho [Ilustrações de Teresa Dias Coelho].

Muralha, S. (1981). Terra e Mar, Vistos do Ar. Horizonte [Ilustrações de Fernando Lemos].

Neves, L. (1977). Amigos em Todo o Mundo. Horizonte [Ilustração da capa de Manuel Correia].

Oliveira, A. (2009). Do Cinzento ao Azul Celeste. Calendário de Letras [Ilustrações de Helena Veloso].

Pereira, J. P. (1999). Álvaro Cunhal: Uma Biografia Politica: $1 .^{\circ}$ vol. - Daniel, o jovem revolucionário (1913-1941). Temas e Debates.

Pereira, J. P. (2001). Álvaro Cunhal: Uma Biografia Política: 2. vol. - "Duarte", o dirigente clandestino (1941-1949). Temas e Debates.

Pereira, J. P. (2005). Álvaro Cunhal: Uma Biografia Politica: 3. ${ }^{\circ}$ vol. - O Prisioneiro (1949-1960). Temas e Debates.

Pereira, J. P. (2016). Álvaro Cunhal: Uma Biografia Política, $4{ }^{\circ}$ vol. - O SecretárioGeral (1960-1968). Temas e Debates.

Pina, M. A. (1976). A revolução das letras. Em O Têpluquê (pp. 8-15). A Regra do Jogo [Ilustrações de João Botelho].

Pina, M. A. (1994). O Tesouro. APRIL e Associação 25 de Abril [Ilustrações de Manuela Bacelar].

Pinhão, C. (1977). Bichos de Abril. Caminho [Ilustrações de João Martins].

Ramos, A. M. (2006). Memórias da Revolução de Abril na Literatura para a Infância: diferentes formas de contar a mesma bistória. http://www.casadaleitura.org/.

Ramos, A. M. (2014). As cores do 25 de Abril na literatura para a infância 40 anos depois da Revolução. Forma Breve, 11, 259-272.

Revolução. (s.f.) Em Dicionário Priberam da Lingua Portuguesa (DPLP) [em linha], 2008-2020, https://dicionario.priberam.org/Revolução (consultado em 11-032019).

Ribeiro, J. M. (2011). O Rapaz sem Orelhas de Burro. Trinta por Uma Linha [Ilustrações de Marta Madureira]. 
Ribeiro, J. M., Franco, J. A., Vicente, M. da C. (2013). 25 de Abril: 40 Anos de Liberdade. Tropelias \& Companhia [Fotografias de António Rilo].

Rosemberg, F. (1985). Literatura Infantil e Ideologia. Global.

Santos, M. F. (2010). 7 × 25 Histórias da Liberdade. Gailivro [Ilustrações de Inês do Carmo].

Soares, L. D. (2003). A Cavalo no Tempo. Civilização [Ilustrações de Teresa Lima].

Soares, L. D. (2009). Dia da Liberdade. Em O Livro das Datas (s.n.). Civilização [Ilustrações de Maria João Lopes].

Stephens, J. (1992). Language and Ideology in Children's Fiction. Longman.

Torrado, A. (2001). Vassourinha. Campo das Letras [Ilustrações de João Abel Manta].

Vaz, J. (2000). A Fábula dos Feijões Cinzentos. 25 de Abril, como quem conta um conto. Campo das Letras, col. Palmo e Meio [Ilustrações de Elsa Navarro].

Vieira, A. (1999). Vinte Cinco a Sete Vozes. Caminho.

Vieira, V. A. (2004). A Revolução das Letras: O 25 de Abril explicado às crianças. Campo das Letras [Ilustrações de Fedra Santos]. 